\title{
PENGEMBANGAN PERANGKAT PEMBELAJARAN INKUIRI TERBIMBING BERBANTUAN PhET PADA MATERI LISTRIK DINAMIS UNTUK MENINGKATKAN KETERAMPILAN BERPIKIR KRITIS SISWA
}

\author{
Neti Nafrianti ${ }^{1)}$, Z. A. Imam Supardi' ${ }^{2}$, Erman $^{3)}$ \\ ${ }^{1)}$ Mahasiswa Program Studi Pendidikan Sains, Program Pascasarjana Universitas Negeri Surabaya \\ ${ }^{2), 3)}$ Dosen Pascasarjana Prodi Pendidikan Sains Univesrtitas Negeri Surabaya \\ E-mail:nety,herman@gmail.com
}

\begin{abstract}
Abstrak: Penelitian pengembangan ini bertujuan untuk menghasilkan perangkat pembelajaran inkuiri terbimbing berbantuan PhET untuk meningkatkan keterampilan berpikir kritis siswa yang layak (valid, praktis dan efektif) digunakan dalam proses belajar mengajar pada materi listrik dinamis di SMP. Untuk mencapai tujuan tersebut, peneliti mengembangkan perangkat pembelajaran yang terdiri atas Rencana Pelaksanaan Pembelajaran, Lembar Kegiatan Siswa, Bahan Ajar Siswa dan Tes Hasil Belajar Keterampilan Berpikir Kritis dengan menggunakan model pengembangan 4-D. Perangkat hasil pengembangan yang telah divalidasi dan direvisi, kemudian diujicobakan pada 30 orang siswa kelas IX SMPN 6 Muaro Jambi dengan menggunakan rancangan One Group Pretest-Posttest. Keterampilan berpikir kritis siswa menunjukkan peningkatan dengan kategori tinggi. Berdasarkan data hasil penelitian, maka dapat disimpulkan bahwa perangkat pembelajaran inkuiri terbimbing berbantuan PhET pada materi Listrik Dinamis layak digunakan untuk meningkatkan keterampilan berpikir kritis siswa.
\end{abstract}

Kata kunci: Keterampilan Berpikir Kritis, Pembelajaran Inkuiri terbimbing, Media Pembelajaran PhET.

\begin{abstract}
This development of research aimed to produce the sets of PhET-assisted guided inquiry learning materials to increase students' critical thinking skills are feasible (valid, practical and efficient) for using in teaching and learning process on dynamic electricity in junior high school. To achieve these objectives, the researcher developed learning materials that contain: Lesson Plan, Student Activity Sheet, Instructional Materials and an instrument to measure critical thinking skill, the 4-D model had been used to develop these materials. They had been validated, revised, and tested to 30 students of IX grade of junior high school 6 muaro jambi using one group pretest-posttest design. Student's critical thinking skill improved by high category. Based on this research result, it can be concluded that the PhET-assisted guided inquiry learning on Dinamycs Electricity is feasible to increase the improvement of student's critical thinking skill.
\end{abstract}

Keywords: Critical Thinking Skills, Guided Inquiry Learning, the Learning Media of PhET

\section{PENDAHULUAN}

Penerapan kurikulum 2013 menyebabkan terjadinya pergeseran paradigma pembelajaran IPA di sekolah dari paradigma teacher-oriented ke student-oriented. Peran guru bergeser dari menentukan "apa yang akan dipelajari siswa" ke "bagaimana menyediakan dan memperkaya pengalaman belajar siswa”. Pengalaman belajar IPA diperoleh melalui serangkaian kegiatan untuk mengeksplorasi lingkungan melalui interaksi aktif dengan teman, lingkungan dan narasumber lain. Pembelajaran IPA yang berpusat pada siswa dan menekankan pentingnya belajar aktif berarti mengubah pola pembelajaran guru yang selalu memberikan informasi dan sumber pengetahuan bagi siswa (National Research Council, 1996).

Berdasarkan paradigma pendidikan dalam Kurikulum 2013, pembelajaran IPA dilakukan dengan menggunakan pendekatan ilmiah yang melibatkan siswa dalam penyelidikan yang berorientasi inkuiri, dan interaksi antara siswa dengan guru dan siswa lainnya. Siswa diarahkan untuk mengembangkan kemampuan berpikir, bernalar, bekerja ilmiah melalui pembelajaran inkuiri dan pengalaman belajar (Kemendikbud, 2013).

Pengalaman yang paling tinggi nilainya adalah pengalaman yang diperoleh dari hasil kontak langsung dengan lingkungan, objek, binatang, manusia dan sebagainya, dengan cara melakukan perbuatan langsung (Zubaidah, 2013). Verbal symbol yang diperoleh melalui penuturan dengan kata-kata merupakan pengalaman belajar yang paling rendah tingkatannya. Oleh karena itu, agar pembelajaran dapat memberikan pengalaman yang lebih berarti bagi siswa, maka perlu dirancang model pembelajaran yang dapat membawa siswa kepada pengalaman yang lebih konkrit.

Berdasarkan observasi dan wawancara yang dilakukan peneliti pada SMP Negeri 6 Muaro Jambi, 
diketahui bahwa dalam proses pembelajaran IPA siswa kurang aktif, meskipun beberapa guru sudah mulai berbenah dengan melakukan upaya perbaikan seperti menyajikan materi pembelajaran dengan menggunakan power point untuk menarik perhatian siswa, menggunakan media seperti charta, torso dan beberapa model pendukung, akan tetapi pembelajaran masih didominasi oleh guru, siswa masih terlihat lebih banyak duduk mendengarkan guru, mencatat dan mengerjakan soal latihan. Proses pembelajaran belum memberikan akses bagi siswa untuk berkembang secara mandiri baik dalam hal memperoleh pengetahuan maupun dalam hal mengasah keterampilan berpikir kritis. Siswa memperoleh pengetahuan dari membaca, mendengarkan penjelasan guru dan sedikit interaksi dengan benda-benda atau lingkungan yang ada di sekitarnya, akibatnya siswa menjadi pasif dan pengetahuan yang diperoleh hanya sebatas apa yang ada dalam buku teks atau hanya informasi yang diperoleh dari guru saja.

Kondisi pembelajaran seperti yang digambarkan di atas menyebabkan keterampilan berpikir kritis dikalangan siswa tidak dapat bertumbuh kembang sesuai dengan harapan. Keterampilan berpikir kritis perlu dilatihkan sedini mungkin agar ketika menyelesaikan masalah yang berhubungan langsung dengan dunia nyata, siswa mampu menjadi problem solvers yang handal berdasarkan pemikiran kritis dalam menentukan pokok permasalahan pada setiap prosedur ilmiah.

Fisher (2009) menyatakan berpikir kritis adalah model berpikir mengenai hal, substansi, atau masalah apa saja dimana sipemikir meningkatkan kualitas pemikirannya dengan menangani secara terampil struktur-struktur yang melekat dalam pemikiran dan menerapkan standar-standar intelektual padanya. Ennis (1996) menyatakan bahwa berpikir kritis adalah sebuah proses yang dalam mengungkap tujuan dilengkapi alasan yang tegas tentang suatu kepercayaan dan kegiatan yang telah dilakukan. Berpikir kritis difokuskan pada pengertian mengenai sesuatu dengan penuh kesadaran dan mengarah pada sebuah tujuan, seperti menjawab pertanyaan, membuat keputusan, memecahkan masalah, menyelesaikan masalah, menyusun rencana, atau melaksanakan percobaan, yang terangkum dalam proses pembelajaran inkuiri terbimbing.

Penelitian Duron, R (2006) menunjukkan bahwa implementasi kerangka berpikir kritis mampu membangun menyelesaikan masalah hidup dan efektif meningkatkan kedisiplinan guru dan siswa. Semakin baik pengembangan kemampuan berpikir kritis, maka siswa akan semakin dapat mengatasi masalah-masalah dalam kehidupan sehari-hari. Dengan pertimbangan bahwa keterampilan berpikir kritis tidak diwariskan secara turun-menurun dari generasi ke generasi, maka sekolah perlu menciptakan lingkungan belajar yang interaktif dan siswa harus terlibat secara aktif dalam pembelajaran agar mereka terbiasa dan terlatih dalam berfikir kritis, salah satunya dengan cara memilih model pembelajaran yang tepat.

Model pembelajaran yang memberikan kesempatan bagi siswa dan membantu siswa mendapatkan pemahaman tentang metode ilmiah guna mengembangkan kemampuan berpikir kritis, pengaturan diri, dan pemahaman tentang topik-topik spesifik adalah model pembelajaran inkuiri (Eggen, 2012). Pembelajaran inkuiri terbimbing memberi kesempatan pada siswa untuk menjawab pertanyaan dan memecahkan masalah sendiri berdasarkan fakta dan observasi. Pembelajaran inkuiri terbimbing dirancang untuk melatih kemampuan siswa tentang bagaimana meneliti masalah dan pertanyaan berdasarkan fakta. Pembelajaran berbasis inkuiri terbimbing mengimplementasikan lima tahap pembelajaran yaitu (1) mengidentifikasi suatu pertanyaan atau masalah, (2) merumuskan hipotesis, (3) mengumpulkan data, (4) menguji hipotesis, dan (5) merumuskan generalisasi (Kardi, 2013). Pembelajaran inkuiri terbimbing dipilih karena dalam pembelajaran aktif siswa masih sangat memerlukan bimbingan gurunya dalam aktivitas kognitif untuk membentuk pengetahuan yang bermakna.

Selain model pembelajaran, media yang digunakan dalam pembelajaran juga merupakan faktor penting yang tidak boleh kita abaikan. Pemilihan media yang tepat dapat menunjang keberhasilan proses pembelajaran. Seiring dengan perkembangan Teknologi Informasi dan Komunikasi (TIK), banyak simulasisimulasi menarik yang bisa kita gunakan sebagai media interaktif untuk membantu pembelajaran. Salah satu media simulasi yang menarik, interaktif ,standar dan valid dalam pembelajaran IPA adalah PhET (Physics Education Technology).

PhET merupakan program komputer sistematis yang tanggap jaman terhadap perkembangan teknologi pembelajaran yang dikembangkan oleh Universitas Colorado di Boulder, Amerika dalam rangka menyediakan simulasi pengajaran dan pembelajaran IPA berbasis laboratorium maya yang memudahkan pendidik karena bisa digunakan untuk pembelajaran di ruang kelas. Simulasi ini ditulis dalam bahasa pemprograman Java dan Flash dan dapat dijalankan dengan menggunakan web browser baku selama plug-in Flash dan Java sudah terpasang.

Simulasi ini juga mampu menghadirkan dan menjelaskan hal-hal abstrak yang tidak dapat diamati secara langsung dalam kehidupan nyata, menyediakan ruang yang cukup untuk bereksperimen karena variabel-variabel yang disediakan bisa diubah secara 
fleksibel sesuai dengan kebutuhan penyelidikan dalam pembelajaran.

Salah satu materi yang abstrak untuk dipahami oleh siswa adalah Listrik Dinamis karena sebagian besar dari apa yang dipelajari pada materi tersebut secara fisis sulit untuk diamati. Meskipun gejala-gejala yang timbul, seperti lampu menyala redup atau terang, sengatan listrik jika kabel listriknya terkelupas bisa dilihat dan dirasakan (makroskopis), tetapi pada materi ini siswa lebih ditekankan untuk memahami penyebab dari munculnya gejala-gejala tersebut. Penyebabpenyebab tersebut adalah karakteristik rangkaian listrik, arus listrik, tegangan, hambatan, energi listrik dll di mana belum ada contoh atau gambar nyata yang dapat mengilustrasikan itu semua. Oleh karena itu, penggunaan PhET dalam pembelajaran Listrik Dinamis sangat diperlukan, agar siswa bisa lebih memahami konsep dan keterkaitan antar variabel yang terlibat dalam rangkaian listrik.

Berikut ini adalah beberapa penelitian yang relevan dengan pemanfaatan media pembelajaran simulasi yang telah terbukti meningkatkan kualitas pembelajaran siswa. Hamid (2012) menyatakan bahwa 79\% dari 32 responsden mencapai nilai di atas Kriteria Ketuntasan Minimum (KKM) yang ditetapkan. Darmawati (2012) menyimpulkan bahwa penerapan pembelajaran penemuan berbasis PhET dapat mengembangkan keterampilan proses sains siswa. Prihatiningtyas (2013) menyatakan bahwa implementasi PhET dalam pembelajaran mampu menuntaskan hasil belajar psikomotor. Sukamto (2014) menyatakan bahwa pembelajaran inkuiri berbantuan PhET pada materi ajar teori kinetik gas yang didukung dengan perangkat pembelajaran yang dinyatakan valid berkualitas dalam melatihkan keterampilan berpikir kritis siswa SMA dengan peningkatan keterampilan yang tinggi.

Pengintegrasian TIK dalam pembelajaran merupakan hal yang wajib dalam kurikulum 2013, dalam penelitian ini pengintegrasian TIK tersebut diwujudkan dalam pemilihan media pembelajarannya yakni media simulasi PhET dimana dalam penggunaannya diperlukan beberapa komponen IT pendukung, selain itu fasilitas sekolah berupa ketersediaan komputer ditempat penelitian juga mendukung dan memadai.

Berdasarkan uraian yang telah dikemukakan dan kondisi nyata di sekolah peneliti yang memiliki fasilitas komputer yang memadai dan mendukung untuk penggunaan $\mathrm{PhET}$ dalam pembelajaran, maka peneliti melakukan penelitian pendidikan dengan judul "Pengembangan Perangkat Pembelajaran Inkuiri Terbimbing Berbantuan PhET pada Materi Listrik Dinamis untuk Meningkatkan Keterampilan Berpikir Kritis siswa SMP”

\section{METODE PENELITIAN}

Penelitian ini merupakan penelitian pengembangan karena mengembangkan perangkat pembelajaran yang meliputi Rencana Pelaksanaan Pembelajaran (RPP), Lembar Kegiatan Siswa (LKS), Tes Hasil Belajar (THB) dan Tes Keterampilan berpikir Kritis dengan menerapkan model pembelajaran inkuiri terbimbing berbantuan PhET. Penelitian ini dilaksanakan untuk menghasilkan perangkat pembelajaran IPA materi Listrik Dinamis, yang selanjutnya akan diujicobakan di kelas.

Penelitian ini menggunakan model One Group Pretest-Postest Designyang dikembangkan oleh Campbell and Stanley dalam Arikunto (2010). Desain penelitian ini dapat digambarkan sebagai berikut:

\section{$\mathrm{O}_{1} \mathrm{X} \mathrm{O}_{2}$}

Keterangan:

$$
\begin{aligned}
& \mathrm{O}_{1}=\text { Uji awal (pretest) } \\
& \mathrm{X}=\text { Pemberian perlakuan } \\
& \mathrm{O}_{2}=\text { Uji akhir (posttest) }
\end{aligned}
$$

Prosedur penelitian menggunakan rancangan pengembangan perangkat pembelajaran model 4D (four D model). Menurut Ibrahim (2002) bahwa untuk merancang perangkat pembelajaran menggunakan four D model terdiri dari empat tahapan yaitu pendefinisian (define), perancangan (design), pengembangan (develop), dan penyebaran (disseminate). Tahap penyebaran peneliti lakukan dengan cara pendistribusian perangkat dalam jumlah terbatas kepada guru dan peserta didik. Menurut Endang (2012) pada konteks pengembangan bahan ajar, tahap dissemination dilakukan dengan cara sosialisasi bahan ajar melalui pendistribusian dalam jumlah terbatas kepada guru dan peserta didik. Pendistribusian ini dimaksudkan untuk memperoleh respons, umpan balik terhadap bahan ajar yang telah dikembangkan. Apabila respon sasaran pengguna bahan ajar sudah baik maka baru dilakukan pencetakan dalam jumlah banyak dan pemasaran supaya bahan ajar itu digunakan oleh sasaran yang lebih luas.Data penelitian diperoleh dari siswa kelas IX SMPN 6 Muaro Jambi Propinsi Jambi. Analisis data dilakukan dengan teknik analisis statistik deskriptif kuantitatif dan kualitatif.

\section{HASIL PENELITIAN DAN DISKUSI}

Berdasarkan hasil analisis data dapat disampaikan beberapa hal sebagai berikut:

\section{A. Kevalidan Perangkat Pembelajaran}

Perangkat pembelajaran yang dikembangkan pada penelitian ini adalah Rencana Pelaksanaan Pembelajaran (RPP), Lembar Kegiatan Siswa (LKS), Buku Ajar Siswa (BAS), dan Tes Keterampilan berpikir kritis. Perangkat pembelajaran dikatakan layak 
digunakan dalam proses pembelajaran, jika dilakukan validasi oleh validator ahli dan uji coba terbatas. Hasil validasi perangkat pembelajaran dapat disimpulkan bahwa: (1) Hasil telaah RPP adalah layak digunakan dan berkategori baik; (2) Hasil telaah LKS adalah layak digunakan dan berkategori baik; (3) Hasil telaah instrumen tes keterampilan berpikir kritis dinyatakan valid dan dapat digunakan dalam proses pembelajaran.

\section{B. Kepraktisan Perangkat Pembelajaran}

1. Keterlaksanaan RPP

Kategori pelaksanaan RPP sangat baik karena semua langkah-langkah yang direncanakan terlaksana $100 \%$. Hasil pengamatan terhadap keterlaksanaan RPP dengan menggunakan model pembelajaran inkuiri terbimbing berbantuan PhET yang dilakukan oleh dua orang pengamat menggunakan lembar pengamatan keterlaksanaan RPP (LPK RPP), didapat persentase kecocokan antar 2 pengamat, dan disajikan secara ringkas pada tebel 1 berikut.

Tabel 1. Persentase Kecocokan LPK RPP

\begin{tabular}{|l|c|c|c|c|}
\hline \multirow{2}{*}{$\begin{array}{l}\text { Pengamatan } \\
\text { terhadap }\end{array}$} & \multicolumn{2}{|l|}{$\begin{array}{l}\text { Persentase Kecocokan Tiap } \\
\text { Pertemuan (\%) }\end{array}$} & \multirow{2}{*}{$\begin{array}{l}\text { Rata- } \\
\text { rata (\%) }\end{array}$} \\
\cline { 2 - 4 } & 1 & 2 & 3 & \\
\hline Guru & 95.81 & 97.67 & 97.18 & 96.89 \\
\hline
\end{tabular}

Persentase kecocokan instrumen pembelajaran pada Tabel 1 menunjukkan bahwa masing-masing RPP melebihi $75 \%$, dengan rata-rata sebesar $96.89 \%$. Keterlaksanaan RPP juga dinyatakan dengan persentase keterlaksanaan dan kualitas nilai keterlaksanaan disajikan pada tabel 2.

Tabel 2. Penilaian Keterlaksanaan RPP

\begin{tabular}{|l|l|l|l|}
\hline No & $\begin{array}{l}\text { Aspek yang } \\
\text { Dinilai }\end{array}$ & $\begin{array}{l}\text { Rata-rata penilain } \\
\text { pengamat tiap pert. }\end{array}$ & Kategori \\
\hline 1 & $\begin{array}{l}\text { Kegiatan } \\
\text { Pendahuluan }\end{array}$ & 3.61 & Baik \\
\hline 2 & Kegiatan Inti & 3.70 & Baik \\
\hline 3 & Penutup & 3.79 & Baik \\
\hline 4 & Suasana kelas & 3.83 & Baik \\
\hline \multicolumn{2}{|l|}{$\begin{array}{l}\text { Rata-rata } \\
\text { keterlaksanaan RPP }\end{array}$} & Baik \\
\hline
\end{tabular}

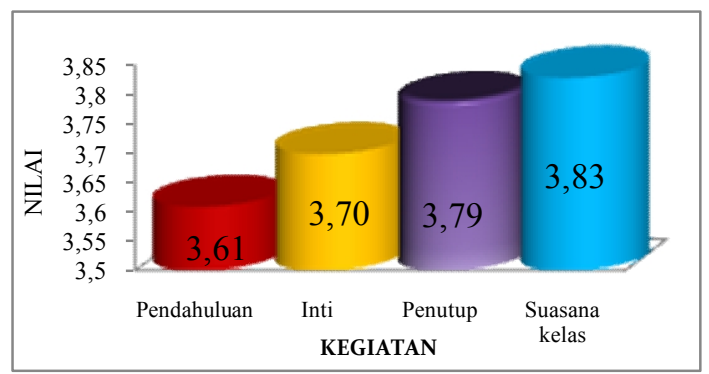

Gambar 1. Keterlaksanaan RPP
Berdasarkan Tabel 2 dan Gambar 1 tentang keterlaksanaan RPP menunjukkan bahwa kemampuan guru dalam melaksanakan pembelajaran meliputi aspek kegiatan pendahuluan dengan nilai 3,61 kategori baik, kegiatan inti nilai 3,70 kategori baik, kegiatan penutup 3,79 kategori baik, dan suasana kelas nilai 3,83 kategori baik. Rata-rata nilai keterlaksanaan RPP sebesar berkategori baik. Hasil analisis data disajikan dari tabel di atas menunjukkan bahwa guru dapat melaksanakan semua skenario pembelajaran yang direncanakan dalam RPP dengan baik.

\section{Aktivitas Siswa}

Aktivitas siswa selama pembelajaran diamati oleh dua orang pengamat menggunakan lembar pengamatan aktivitas siswa (LPAS). Persentase kecocokan 2 pengamat dengan menggunakan lembar pengamatan aktivitas siswa (LPAS) disajikan pada Tabel 3.

Tabel 3. Persentase Kecocokan Lembar Pengamatan Aktivitas Siswa dalam KBM

\begin{tabular}{|l|c|c|c|c|}
\hline \multirow{2}{*}{$\begin{array}{l}\text { Pengamatan } \\
\text { terhadap }\end{array}$} & \multicolumn{2}{|c|}{$\begin{array}{l}\text { Persentase Kecocokan } \\
\text { tiap Pertemuan (\%) }\end{array}$} & \multirow{2}{*}{ Rata-rata (\%) } \\
\cline { 2 - 4 } & 1 & 2 & 3 & \\
\hline Siswa & 98 & 97 & 98 & 97.67 \\
\hline
\end{tabular}

Tabel 3 menunjukkan bahwa rata-rata persentase kecocoka lembar pengamatan aktivitas siswa yaitu sebesar $97.67 \%$ nilai ini melebihi $75 \%$ dengan demikian dapat dikatakan bahwa instrumen berkategori baik dan dapat digunakan untuk proses pengamatan. Data aktivitas siswa selama KBM disajikan dalam Tabel 4.

Tabel 4. Aktivitas Siswa selama KBM

\begin{tabular}{|c|c|c|}
\hline No. & Aspek Yang Diamati & $\begin{array}{l}\text { Rata-rata } \\
\text { Aktivitas } \\
\text { siswa (\%) }\end{array}$ \\
\hline 1 & $\begin{array}{l}\text { Mendengar } / \text { memperhatikan } \\
\text { penjelasan guru }\end{array}$ & 13.26 \\
\hline 2 & $\begin{array}{l}\text { Membaca (mencari informasi } \\
\text { tentang materi ) }\end{array}$ & 16.82 \\
\hline 3 & $\begin{array}{l}\text { Melakukan percobaan sesuai } \\
\text { panduan LKS }\end{array}$ & 13,17 \\
\hline 4 & $\begin{array}{l}\text { Melakukan pengamatan } \\
\text { pengambilan data } \\
\text { petunjuk pada LKS }\end{array}$ & 12.88 \\
\hline 5 & $\begin{array}{l}\text { Mencatat data hasil pengamatan } \\
\text { sesuai LKS }\end{array}$ & 11.80 \\
\hline 6 & $\begin{array}{l}\text { Mendiskusikan tugas } \\
\text { pertanyaan dalam LKS }\end{array}$ & 6.93 \\
\hline 7 & Menjawab pertanyaan guru & 7.53 \\
\hline 8 & $\begin{array}{l}\text { Menyampaikan pendapat / } \\
\text { mengkomunikasikan informasi } \\
\text { kepada kelas / guru }\end{array}$ & 7.71 \\
\hline 9 & Bertanya pada teman dan guru & 9.20 \\
\hline 10 & Perilaku tidak relevan & 0.69 \\
\hline & Jumlah & 100 \\
\hline
\end{tabular}




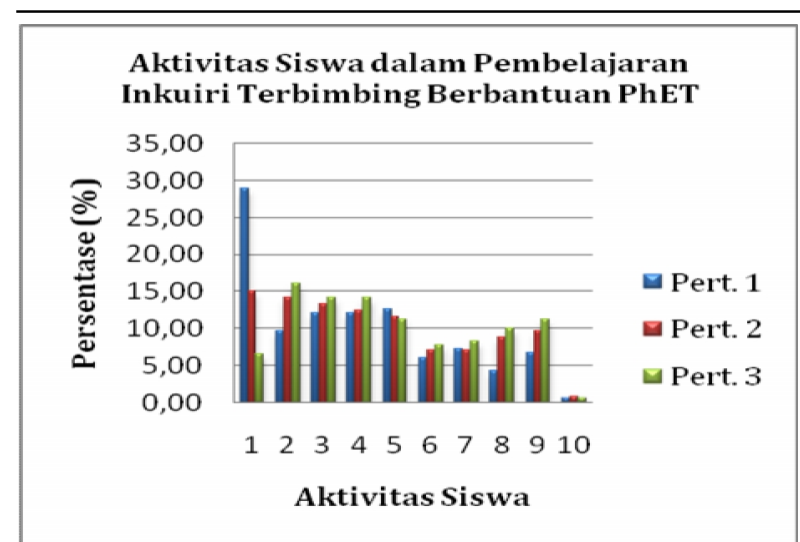

Gambar 2. Persentase Aktivitas Siswa

Berdasarkan diagram batang tentang persentase aktivitas siswa dakam KBM, dapat dikemukakan bahwa persentase aktivitas yang dominan dilakukan siswa adalah membaca (mencari informasi tentang materi yang sedang dipelajari, yaitu $16,82 \%$. Aktivitas yang dilakukan siswa tersebut menunjukkan bahwa rasa ingin tahu siswa terhadap meteri listrik dinamis tinggi. Hal ini memberikan kesempatan kepada siswa untuk aktif dalam menemukan konsep dan berlatih berpikir kritis untuk menemukan hubungan dan membuat kesimpulan berdasarkan data eksperimennya. Sesuai dengan tujuan Kurikulum 2013 untuk menghasilkan peserta didik sebagai manusia yang mandiri dan tak berhenti belajar, proses pembelajaran dalam RPP dirancang berpusat pada peserta didik untuk mengembangkan motivasi, rasa ingin tahu, kreativitas, kemandirian, keterampilan belajar dan mendorong partisipasi aktif peserta didik (Permendikbud No. 81A).

\section{Hambatan yang Ditemui}

Hambatan yang ditemui selama penerapan perangkat pembelajaran inkuiri terbimbing berbantuan PhET untuk meningkatkan keterampilan berpikir kritis relatif baru dan belum terbiasa bagi siswa. Terutama langkah-langkah pembelajaran inkuiri terbimbing. Sehingga untuk mengatasi masalah ini peneliti memerlukan waktu sendiri untuk menjelaskan bagaimana proses belajar menggunakan pembelajaran inkuiri terbimbing. Hambatan lainnya adalah pada pertemuan pertama, tidak semua siswa aktif dalam proses KBM terutama pada saat melakukan percobaan serta mengerjakan LKS, sebagian dari mereka masih terlihat mengoperasikan PhET setelah pengambilan data selesai, sehingga sedikit saja yang terlibat dalam diskusi kelompok untuk analisis data, menjawab soal dan membuat kesimpulan akibatnya laporan selesai tidak tepat waktu.

\section{Kefektifan Perangkat Pembelajaran \\ 1. Respon Siswa}

Respon siswa terhadap pembelajaran inkuiri terbimbing berbantuan PhET dengan menggunakan lembar angket respon siswa (LARS). Angket respon siswa diisi setelah pembelajaran selesai. Data yang diperoleh pada Tabel 5 .

Tabel 5. Respon Siswa Terhadap Pembelajaran Inkuiri Terbimbing Berbantuan PhET

\begin{tabular}{|c|c|c|c|}
\hline No. & Uraian Pertanyaan & \multicolumn{2}{|c|}{ Penilaian/ Pendapat (\%) } \\
\hline \multirow{7}{*}{ I } & $\begin{array}{l}\text { Bagaimana pendapat } \\
\text { anda terhadap } \\
\text { komponen berikut } \\
\text { ini? }\end{array}$ & Senang & $\begin{array}{l}\text { Tidak } \\
\text { Senang }\end{array}$ \\
\hline & 1. Materi/isi pelajaran & 100 & 0 \\
\hline & 2. Buku siswa & 100 & 0 \\
\hline & 3. Lembar kerja siswa & 100 & 0 \\
\hline & 4. Suasana belajar & 93 & 7 \\
\hline & 5. Cara guru mengajar & 100 & 0 \\
\hline & Rata-rata & 99 & 1 \\
\hline \multirow{7}{*}{ II } & $\begin{array}{l}\text { Apakah anda merasa } \\
\text { baru terhadap } \\
\text { komponen-komponen } \\
\text { berikut ini? }\end{array}$ & $\begin{array}{l}\text { Sangat } \\
\text { baru }\end{array}$ & $\begin{array}{l}\text { Tidak } \\
\text { baru }\end{array}$ \\
\hline & 1. Materi/isi pelajaran & 87 & 13 \\
\hline & 2. Buku siswa & 100 & 0 \\
\hline & 3. Lembar kerja siswa & 100 & 0 \\
\hline & 4. Suasana belajar & 100 & 0 \\
\hline & 5.Cara guru mengajar & 100 & 0 \\
\hline & Rata-rata & 97 & 3 \\
\hline \multirow{7}{*}{ III } & $\begin{array}{l}\text { Apakah anda dengan } \\
\text { mudah dapat } \\
\text { memahami } \\
\text { komponen-komponen } \\
\text { berikut ini? }\end{array}$ & Mudah & $\begin{array}{l}\text { Tidak } \\
\text { mudah }\end{array}$ \\
\hline & 1. Bahasa dalam buku & 100 & 0 \\
\hline & 2. Materi isi buku & 100 & 0 \\
\hline & $\begin{array}{l}\text { 3. Lembar Kegiatan } \\
\text { Siswa }\end{array}$ & 100 & 0 \\
\hline & 4. Lembar evaluasi & 100 & 0 \\
\hline & $\begin{array}{ll}5 . \quad \text { Cara guru } \\
\text { mengajar }\end{array}$ & 100 & 0 \\
\hline & Rata-rata & 100 & 0 \\
\hline \multirow{6}{*}{ IV } & \begin{tabular}{lr}
\multicolumn{2}{l}{ Apakah anda merasa } \\
berminat & terhadap \\
LKS & inkuiri \\
terbimbing & \\
\end{tabular} & Berminat & $\begin{array}{l}\text { Tidak } \\
\text { berminat }\end{array}$ \\
\hline & 1. Menentukan tujuan & 87 & 13 \\
\hline & $\begin{array}{l}\text { 2.Melakukan } \\
\text { eksperimen } \\
\text { /pengamatan } \\
\end{array}$ & 100 & 0 \\
\hline & 3. Menganalisis data & 90 & 10 \\
\hline & $\begin{array}{ll}4 . & \text { Membuat } \\
\text { kesimpulan }\end{array}$ & 87 & 13 \\
\hline & Rata-rata & 91 & 9 \\
\hline V & & Setuju & Tidak \\
\hline
\end{tabular}




\begin{tabular}{|c|c|c|c|}
\hline \multirow[t]{5}{*}{ No. } & Uraian Pertanyaan & \multicolumn{2}{|c|}{ Penilaian/ Pendapat $(\%$} \\
\hline & & & Setuju \\
\hline & 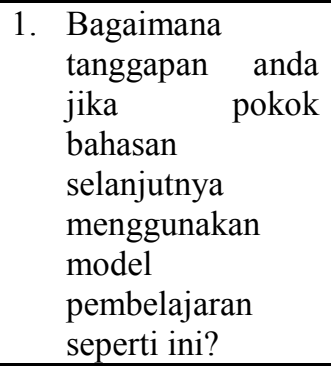 & 83 & 17 \\
\hline & $\begin{array}{l}\text { 1. Bagaimana } \\
\text { pendapat anda } \\
\text { jika pelajaran lain } \\
\text { diajarkan dengan } \\
\text { menggunakan } \\
\text { pembelajaran } \\
\text { seperti ini? } \\
\end{array}$ & 83 & 17 \\
\hline & Rata-rata & 83 & 17 \\
\hline \multirow{4}{*}{ VI } & & Jelas & $\begin{array}{l}\text { Tidak } \\
\text { Jelas }\end{array}$ \\
\hline & $\begin{array}{l}\text { Bagaimana } \\
\text { penjelasan guru } \\
\text { pada saat KBM } \\
\text { berlangsung? } \\
\end{array}$ & 100 & 0 \\
\hline & $\begin{array}{l}\text { 2. } \\
\text { bimbingan guru } \\
\text { pada saat anda } \\
\text { menemukan } \\
\text { konsep melalui } \\
\text { eksperimen/meng } \\
\text { erjakan LKS } \\
\text { selama } \\
\text { pembelajaran? }\end{array}$ & 100 & 0 \\
\hline & Rata-rata & 100 & 0 \\
\hline \multirow{4}{*}{ VII } & & Mudah & $\begin{array}{l}\text { Tidak } \\
\text { Mudah }\end{array}$ \\
\hline & $\begin{array}{lr}\text { Apakah } & \text { anda dengan } \\
\text { mudah menjawab } \\
\text { butir } & \text { soal } \\
\text { pengetahuan? } & \end{array}$ & 93 & 7 \\
\hline & $\begin{array}{l}\text { Apakah anda dengan } \\
\text { mudah untuk } \\
\text { menjawab butir soal } \\
\text { keterampilan berpikir } \\
\text { kritis? }\end{array}$ & 83 & 17 \\
\hline & Rata-rata & 88 & 12 \\
\hline \multicolumn{2}{|c|}{ Rata-rata keseluruhan respon } & 93,05 & 6,95 \\
\hline
\end{tabular}

Berdasarkan analisis data di atas dapat disimpulkaan bahwa siswa memberikan respon positif dan baik terhadap pembelajaran inkuiri terbimbing berbantuan PhET pada materi Listrik Dinamis.

\section{Keterampilan Berpikir Kritis Siswa}

Sebelum dan setelah proses pembelajaran berlangsung di kelas, dilakukan tes terhadap keterampilan berpikir kritis siswa (Nieveen, 1999).
Berikut disajikan persentase peningkatan keterampilan berpikir kritis siswa secara klasikal sebelum dan setelah pembelajaran inkuiri terbimbing berbantuan PhET diterapkan.

Tabel 6. Persentase Keterampilan berpikir Kritis Siswa

\begin{tabular}{|c|l|c|c|}
\hline \multirow{2}{*}{ NO } & \multirow{2}{*}{ Tingkatan } & \multicolumn{2}{|c|}{ Jumlah siswa (\%) } \\
\cline { 3 - 4 } & & Pretest & Postest \\
\hline 1. & Sangat Terampil & 0,0 & 60,0 \\
\hline 2. & Terampil & 0,0 & 40,0 \\
\hline 3. & Agak Terampil & 26,7 & 0,0 \\
\hline 4. & Tidak Terampil & 73,3 & 0,0 \\
\hline
\end{tabular}

Tabel 6 menunjukan bahwa keterampilan berpikir kritis secara klasikal mengalami peningkatan dari yang awalnya 8 orang siswa $(26,7 \%)$ dari 30 orang siswa berada pada tingkatan agak terampil dan sebanyak 22 orang lainnya $(73,3 \%)$ tidak terampil meningkat menjadi $40,0 \%$ (12 orang) siswa berada pada tingkatan terampil dan 18 orang $(60,0 \%)$ sudah sangat terampil. Analisis data keterampilan berpikir kritis masingmasing siswa sebelum dan setelah penerapan pembelajaran inkuiri terbimbing berbantuan PhET.

Peningkatan skor keterampilan berpikir kritis masing-masing siswa pada uji II dapat dilihat dari nilai $N$-Gain yang mereka peroleh (terlampir di lampiran $5 \mathrm{M}$ ), secara ringkas $\mathrm{N}$-Gain masing-masing siswa dapat digambarkan dalam diagram batang $N$-gain (Borich, 1994) seperti Gambar berikut.

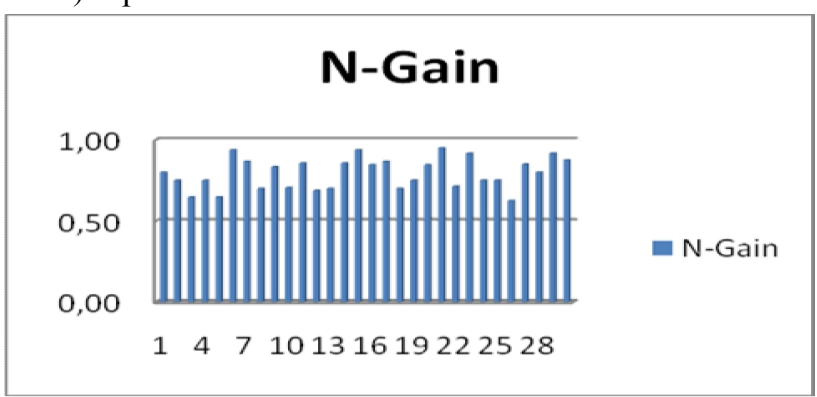

Diagram batang N-Gain menunjukkan bahwa semua siswa mengalami peningkatan dalam berpikir kritis. Empat orang dari 30 orang siswa, yakni siswa nomor urut 3, 5, 12 dan 26 mengalami peningkatan berpikir kritis dengan kategori sedang, sedangkan 26 orang lainnya mengalami peningkatan berpikir kritis dengan kategori tinggi, sehingga dapat disimpulkan bahwa ratarata peningkatan berpikir kritis siswa setelah diterapkan pembelajaran inkuiri terbimbing berbantuan PhET berkategori tinggi.

\section{PENUTUP}

\section{A. Simpulan}

Berdasarkan analisis, pembahasan, dan temuan hasil penelitian dapat disimpulkan bahwa perangkat pembelajaran inkuiri terbimbing berbantuan PhET layak (valid, praktis, dan efektif) digunakan untuk 
meningkatkan keterampilan berpikir kritis siswa pada materi listrik dinamis.

\section{B. Saran}

Beberapa saran dari hasil penelitian yang dilakukan adalah sebagai berikut:

1. Berdasarkan analisis hasil tes keterampilan berpikir kritis siswa, disarankan pada peneliti berikutnya yang ingin melakukan penelitian yang sama untuk melakukan penelitian pada materi IPA yang berbeda dengan melakukan penyesuaian-penyesuaian tertentu sesuai materi yang dipilih.

2. Untuk sekolah yang belum pernah menerapakan pembelajaran inkuiri terbimbing, disarankan untuk meningkatkan bobot dalam melatihkan dan membimbing fase merumuskan masalah, karena fase ini sangat menentukan keberhasilan fase-fase berikutnya. Bobot bimbingan dapat dikurangi secara bertahap bergantung pada kesiapan siswa.

3. Perangkat yang dikembangkan sudah layak (valid, praktis dan efektif) untuk diterapkan, namun perlu penyesuaian-penyesuaian jika diterapkan pada sekolah lain yang kondisinya berbeda.

\section{REFERENSI}

Arends, R. I. (2012). Learning to teach, ninth edition. New York: McGraw-Hill.

Arikunto, S. (2010). Prosedur Penelitian: Suatu Pendekatan Praktik. Jakarta: Rineka Cipta.

Borich, G.D. (1994). Observation Skills for Effective Teaching. New York: Mac Millan Publishing Company.

Darmawati. (2012). Model pembelajaran inkuiri berbasis paket program simulasi PhET untuk melatihkan keterampilan proses sains siswa pada konsep listrik dinamis (Tesis). Surabaya Universitas Negeri, Surabaya.

Duron, R. (2006). "Critical Thinking Framework For Any Discipline. International Journal of Teaching and Learning in Higher Education. Volume 17, Number2, 160-166. ISSN 18129129.

Endang, M. 2012. Pengembangan Model Pembelaharan. Diambil 05 Januari 2016 dari staff.uny.ac.id/sites/default/files/pengembangan model pembelajaran/pdf.

Ennis, R.H. (1996). Critical Thinking. New Jersey: The New York Times Company

Eggen,P.D \& Kauchak. (2012). Strategies for Teachers Teaching Content and Thingking Skill. Boston: Allyn and Bacon

Fisher, A.(2009). Critical Thinking an Introduction. Sevent Edition. Boston: Allyn and Bacon.
Hamid, H. (2012). Pengembangan multimedia pembelajaran berbasis flash pada mata pelajaran ipa fisika materi gerak untuk meningkatkan hasil belajar siswa kelas vii sekolah menengah pertama (Tesis). Universitas Negeri Surabaya: Surabaya.

Hassaoubah, Z.I. (2004). Developing creative and critical thinking skills, cara berpikir kreatif dan kritis. Diterjemahkan oleh Bambang Suryadi. Bandung: Penerbit Nuansa.

Ibrahim, M. (2002). Pengembangan Perangkat Pembelajaran (Modul Terintegrasi Berbasis Kompetensi Guru Mata Pelajaran Biologi SLTP). Jakarta Depdiknas

Kardi, Soeparman. (2013). Model Pembelajaran Langsung Inkuiri Sains Teknologi dan Masyarakat. Surabaya : Universitas Negeri Surabaya.

Kementerian Pendidikan dan Kebudayaan. (2013). Modul Pelatihan Implementaasi Kurikulum 2013. Jakarta: Badan Pengembangan Sumber Daya Manusia Pendidikan dan Kebudayaan dan Penjaminan Mutu Pendidikan.

Kemendikbud. (2014). Ilmu Pengetahuan Alam Kelas IX Buku Guru Edisi revisi 2014. Jakarta : Kementerian Pendidikan dan Kebudayaan.

Nieveen, Nienke. (1999). Proptotyping to reach product quality. Dalam Akker. J.V.D. Design approach and tools in education and training. Kluwer Akademic : Springer Science Business Media, B.V.

NRC (National Research Council). (1996). The many levels of inquiry. Washington : National Academy Press.

Prihatiningtyas, S., Prastowo, T., dan Jatmiko, B. (2013). "Imlementasi simulasi PhET dan KIT sederhana untuk mengajarkan keterampilan psikomotor siswa pada pokok bahasan alat optik". Jurnal pendidikan IPA Indonesia. http://journal.unnes.ac.id/nju/index.php/jpii.

Diunduh pada 15 Desember 2015.

Sukamto, I. (2014). Pengembangan Perangkat Pembelajaran Inkuiri Berbantuan PhET pada Materi Ajar Teori Kinetik Gas untuk Melatihkan Keterampilan Berpikir Kritis Siswa SMA (Tesis). Universitas Negeri Surabaya: Surabaya.

Zubaidah, S, Mahanal, S, dan Yuliati, L. (2013). Ragam Model Pembelajaran IPA SMP Malang : Universitas Negeri Malang. 